\title{
Computational evidence for intramolecular hydrogen bonding and nonbonding $X \cdots O$ interactions in 2'-haloflavonols
}

\author{
Tânia A. O. Fonseca ${ }^{1}$, Matheus P. Freitas ${ }^{* 1}$, Rodrigo A. Cormanich ${ }^{2}$, \\ Teodorico C. Ramalho ${ }^{1}$, Cláudio F. Tormena ${ }^{2}$ and Roberto Rittner ${ }^{2}$
}

\section{Full Research Paper}

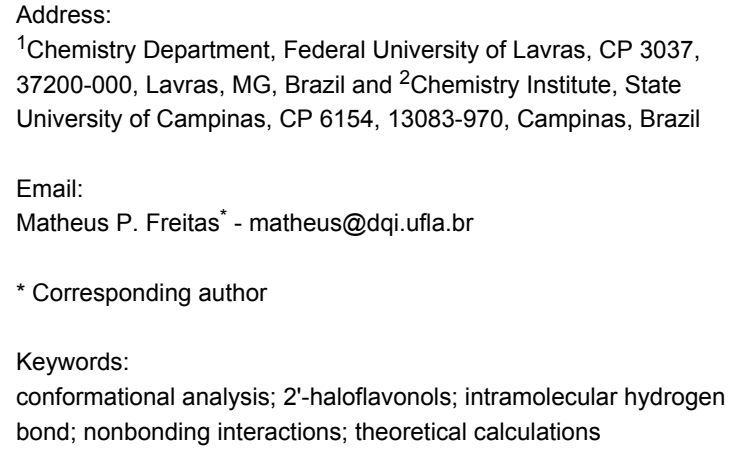

\author{
Beilstein J. Org. Chem. 2012, 8, 112-117. \\ doi:10.3762/bjoc.8.12 \\ Received: 03 November 2011 \\ Accepted: 28 December 2011 \\ Published: 19 January 2012 \\ Associate Editor: J. Murphy \\ C 2012 Fonseca et al; licensee Beilstein-Institut. \\ License and terms: see end of document.
}

\begin{abstract}
The conformational isomerism and stereoelectronic interactions present in 2'-haloflavonols were computationally analyzed. On the basis of the quantum theory of atoms in molecules (QTAIM) and natural bond orbital (NBO) analysis, the conformer stabilities of 2'-haloflavonols were found to be dictated mainly by a $\mathrm{C}=\mathrm{O} \cdots \mathrm{H}-\mathrm{O}$ intramolecular hydrogen bond, but an unusual $\mathrm{C}-\mathrm{F} \cdots \mathrm{H}-\mathrm{O}$ hydrogen-bond and intramolecular $\mathrm{C}-\mathrm{X} \cdots \mathrm{O}$ nonbonding interactions are also present in such compounds.
\end{abstract}

\section{Introduction}

Intermolecular hydrogen bonding (HB) is an interaction governing self-assembly and is responsible for the architecture and organization of molecular aggregates [1], and also ligand-receptor interactions that are responsible for the bioactivity of compounds [2]. Moreover, intramolecular HB has been found to govern the conformational preference of molecules [3]. Intramolecular HB involving halogens $(\mathrm{X})$ is less common than those involving oxygen or nitrogen as proton acceptors, while fluorine when bonded to carbon hardly ever participates in HB [4]. Even more unusual stabilizing interactions are the nonbonding $\mathrm{F} \cdots \mathrm{O}$ interactions, which were experimentally and theoretically characterized in anthracene derivatives, and were pointed out to be the responsible interactions behind the unusual "through-space" fluorine-fluorine spin-spin coupling in the $\mathrm{F} \cdots \mathrm{O} \cdots \mathrm{F}$ fragment present in such a molecular system $[5,6]$. Although not completely understood, nonbonding F $\cdots \mathrm{O}$ interactions, as well as many other unusual long-range interactions involving halogen atoms, are found in several molecular systems in the literature [7-9]. Such weak interactions are more ubiquitous than one imagines and can determine crystal struc- 
tures [10] and the binding of biological molecules [11] and may possibly be the main forces in determining conformational preferences in molecular systems.

2'-Haloflavonols are important compounds with widespread use as bioactive molecules (antioxidant, anti-inflammatory, antiviral, etc.) [12]. The goal of this work is to understand the intramolecular forces determining the preferred conformations of these molecules through the use of DFT theoretical calculations, quantum theory of atoms in molecules (QTAIM) [13-17] and natural bond orbital (NBO) [18] methods. Possible intramolecular $\mathrm{HB}$ and nonbonding $\mathrm{F} \cdots \mathrm{O}$ interactions are narrowly analyzed and the possible effects of such long-range interactions in determining the rotational isomerism of 2'-haloflavonols are discussed.

\section{Results and Discussion}

2'-Haloflavonols undergo rotational isomerization around the $\alpha$ $[\mathrm{H}-\mathrm{O}-\mathrm{C}-\mathrm{C}(=\mathrm{O})]$ and $\beta[\mathrm{C}(\mathrm{X})-\mathrm{C}-\mathrm{C}-\mathrm{C}(\mathrm{OH})]$ torsional angles (Figure 1), giving the energy minima obtained at the B3LYP/ aug-cc-pVDZ level depicted in Table 1. Flavonol itself $(X=H)$ exhibits two stable conformers, with the most stable one having the hydroxy hydrogen directed toward the carbonyl oxygen (conformer A), establishing an intramolecular HB as the stabilizing interaction of this conformation, in agreement with the crystal structure of 2'-methoxyflavonol [19] and with the bioactive conformation of fisetin [20] and quercetin [21]. Moreover, a weak $(\mathrm{H}) \mathrm{O} \cdots \mathrm{H}-\mathrm{C} \mathrm{HB}$ also takes place in flavonol (see<smiles>[X]c1ccccc1C1(O)Oc2ccccc2C(=O)C1(C)O</smiles>

Figure 1: 2'-Haloflavonols and the $\alpha$ and $\beta$ torsional angles.
Supporting Information File 1). NBO analysis at the B3LYP/ aug-cc-pVDZ level gives the hyperconjugation contribution for this interaction $\left(n_{(\mathrm{C}=) \mathrm{O}} \rightarrow \sigma^{*} \mathrm{OH}\right)$ as $6.9 \mathrm{kcal} \mathrm{mol}^{-1}$, while the QTAIM data confirms the establishment of intramolecular HB as a stable, electrostatic interaction (see below).

Among the QTAIM descriptors, the Popelier [17] criteria are useful for the detection and characterization of HB's, as employed here. The first Popelier criterion is the formation of a bond path between the atoms involved in HB. However, speculation about whether the bond paths obtained from QTAIM may represent steric interactions has been the topic of several discussions in the literature $[22,23]$. Bader gave special attention to such a question and considered it as a misinterpretation from the QTAIM and physics itself. Indeed, Bader showed that the presence of a bond path linking a pair of atoms fulfills the sufficient and necessary conditions that the atoms are bonded to one another; therefore, the presence of a bond path (together with a $\mathrm{BCP}$ and an interatomic surface) always indicates an attractive interaction between two atoms [24-26].

According to Table 2, both the Laplacian of the electronic density $\left(\nabla^{2} \rho\right)$ and the total energy $\left(H_{\mathrm{C}}\right)$ at the HB bond critical point (BCP) [27] are positive, and the $\mid V_{\mathrm{C}} / G_{\mathrm{C}}$ ratio [28] (where, $V_{\mathrm{C}}=$ potential energy and $G_{\mathrm{C}}=$ kinetic energy values at the critical points) is smaller than 1 for the HB's, indicating the electrostatic character of such interactions, except for the $(\mathrm{C}=) \mathrm{O} \cdots \mathrm{H}(\mathrm{O})$ interaction in $2^{\prime}$-fluoroflavonol $\mathrm{A}$, which is slightly covalent and, hence, stronger than the remaining ones. The distances between the atoms involved in long-range interactions depicted in Table 2 are always shorter than the sum of their van der Waals radii (the van der Waals radii are tabulated in [29]), i.e., such a geometric parameter is fulfilled by all of these interactions, indicating the possibility of their formation [30]. Indeed, when considering the Popelier criteria, the HB's depicted in Figure 2 and Table 2 are stable and, hence, affect

\begin{tabular}{|c|c|c|c|c|c|c|c|c|}
\hline$x$ & Conf. & $\mathrm{E}_{\mathrm{rel}}$ & $\alpha$ & $\beta$ & $d_{C-x}$ & $n_{\mathrm{O}(=\mathrm{C})} / \sigma^{*} \mathrm{OH}$ & $n_{\mathrm{X}} / \sigma^{*} \mathrm{OH}$ & $n_{X} / \pi^{*} \mathrm{C} 1 \mathrm{C} 2+\mathrm{C} 1 \mathrm{C} 6$ \\
\hline \multirow[t]{2}{*}{$\mathrm{H}$} & $A$ & 0 & 0.0 & 0.0 & 1.08 & $0.8+6.1$ & - & - \\
\hline & $\mathrm{D}$ & 9.8 & 168.5 & 315.4 & 1.08 & - & - & - \\
\hline \multirow[t]{4}{*}{$\mathrm{F}$} & $A$ & 0 & 1.1 & 220.0 & 1.35 & $0.6+5.0$ & - & $19.2+6.0$ \\
\hline & B & 0.5 & 2.0 & 49.3 & 1.35 & $0.5+4.4$ & - & $19.7+6.4$ \\
\hline & C & 7.8 & 150.7 & 43.0 & 1.37 & - & $1.1+2.6+4.6$ & $15.7+6.3$ \\
\hline & $\mathrm{D}$ & 8.5 & 172.9 & 121.4 & 1.35 & - & - & $19.7+6.3$ \\
\hline \multirow[t]{2}{*}{$\mathrm{Cl}$} & A & 0 & 0.9 & 232.0 & 1.76 & $0.6+4.6$ & - & $13.0+3.3$ \\
\hline & $\mathrm{D}$ & 7.9 & 174.8 & 114.0 & 1.75 & - & - & $5.0+13.0$ \\
\hline \multirow[t]{2}{*}{$\mathrm{Br}$} & $A$ & 0 & 0.9 & 234.0 & 1.92 & $0.5+4.6$ & - & $10.2+2.4$ \\
\hline & $D$ & 7.8 & 175.5 & 110.7 & 1.91 & - & - & $4.0+10.1$ \\
\hline
\end{tabular}




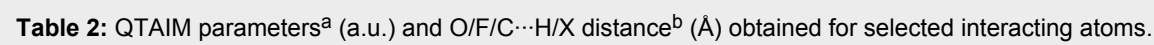

\begin{tabular}{|c|c|c|c|c|c|c|c|}
\hline X (Conformer) & $\mathrm{O} / \mathrm{F} / \mathrm{C} \cdots \mathrm{H} / \mathrm{X}$ & $\rho_{\mathrm{BCP}}$ & $\nabla^{2} \rho_{\mathrm{BCP}}$ & $v_{C}$ & $G_{C}$ & $H_{\mathrm{C}}$ & $\left|V_{C}\right| / G_{C}$ \\
\hline \multicolumn{8}{|l|}{$H(A)$} \\
\hline$(\mathrm{C}=) \mathrm{O} \cdots \mathrm{H}(\mathrm{O})$ & 1.981 & 0.028 & +0.108 & -0.0232 & -0.0232 & 0.0019 & 0.9243 \\
\hline$(\mathrm{C}=) \mathrm{O} \cdots \mathrm{H}(\mathrm{C})$ & 2.647 & 0.018 & +0.074 & -0.0124 & -0.0124 & 0.0030 & 0.8052 \\
\hline \multicolumn{8}{|l|}{$\mathrm{H}(\mathrm{B})$} \\
\hline $\mathrm{C} \cdots \mathrm{H}(\mathrm{O})$ & 2.431 & 0.013 & +0.045 & -0.0008 & -0.0008 & 0.0002 & 0.8889 \\
\hline \multicolumn{8}{|l|}{$F(A)$} \\
\hline$(\mathrm{C}=) \mathrm{O} \cdots \mathrm{H}(\mathrm{O})$ & 2.031 & 0.027 & +0.091 & -0.0229 & -0.0229 & -0.0001 & 1.0044 \\
\hline$(\mathrm{H}) \mathrm{O} \cdots \mathrm{H}(\mathrm{C})$ & 2.499 & 0.010 & +0.041 & -0.0071 & -0.0071 & 0.0016 & 0.8161 \\
\hline$(\mathrm{C}) \mathrm{O}(\mathrm{C}) \cdots \mathrm{F}$ & 2.703 & 0.012 & +0.054 & -0.0112 & -0.0112 & 0.0011 & 0.9106 \\
\hline \multicolumn{8}{|l|}{$F(B)$} \\
\hline$(\mathrm{C}=) \mathrm{O} \cdots \mathrm{H}(\mathrm{O})$ & 2.057 & 0.025 & +0.099 & -0.0199 & -0.0199 & 0.0024 & 0.8924 \\
\hline$(\mathrm{H}) \mathrm{O} \cdots \mathrm{F}$ & 2.794 & 0.010 & +0.042 & -0.0087 & -0.0087 & 0.0009 & 0.9063 \\
\hline \multicolumn{8}{|l|}{$F(C)$} \\
\hline $\mathrm{F} \cdots \mathrm{H}(\mathrm{O})$ & 1.853 & 0.028 & +0.102 & -0.0247 & -0.0247 & 0.0005 & 0.9841 \\
\hline \multicolumn{8}{|l|}{$\mathrm{Cl}(\mathrm{A})$} \\
\hline$(\mathrm{C}=) \mathrm{O} \cdots \mathrm{H}(\mathrm{O})$ & 2.047 & 0.025 & +0.099 & -0.0202 & -0.0202 & 0.0023 & 0.8978 \\
\hline$(\mathrm{C}) \mathrm{O}(\mathrm{C}) \cdots \mathrm{Cl}$ & 3.069 & 0.011 & +0.043 & -0.0076 & -0.0076 & 0.0016 & 0.8352 \\
\hline \multicolumn{8}{|l|}{$\mathrm{Br}(\mathrm{A})$} \\
\hline$(\mathrm{C}=) \mathrm{O} \cdots \mathrm{H}(\mathrm{O})$ & 2.050 & 0.025 & +0.099 & -0.0201 & -0.0201 & 0.0023 & 0.8973 \\
\hline (C)O(C) $\cdots \mathrm{Br}$ & 3.189 & 0.010 & +0.038 & -0.0070 & -0.0070 & 0.0013 & 0.8537 \\
\hline
\end{tabular}

${ }^{\mathrm{a}} \rho_{\mathrm{BCP}}=$ electronic density along with BCP; $\nabla^{2} \rho_{\mathrm{BCP}}=$ Laplacian of the electronic density along with BCP. ${ }^{\mathrm{b}} \mathrm{O} / \mathrm{F} / \mathrm{C} \cdots \mathrm{H} / \mathrm{X}=\mathrm{distance}$ between longrange interacting oxygen/fluorine/carbon and hydrogen/halogen atoms.

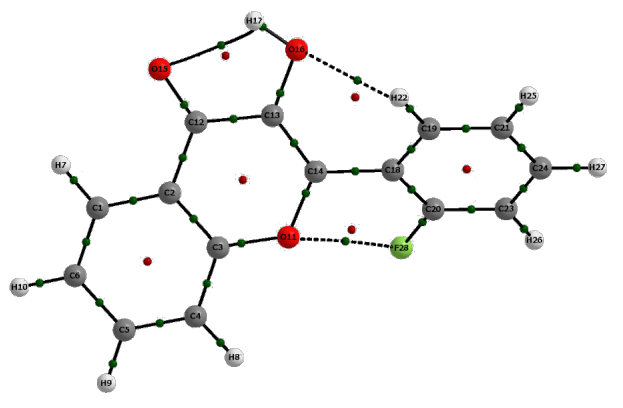

A

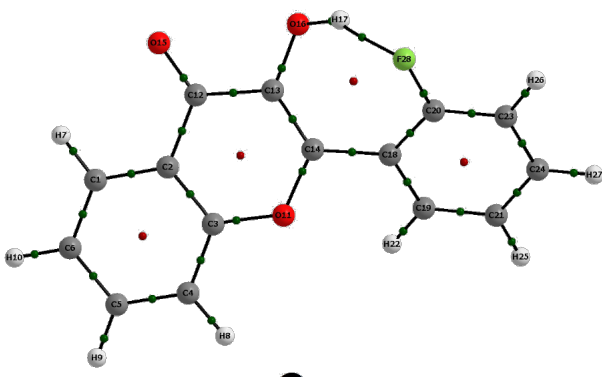

C

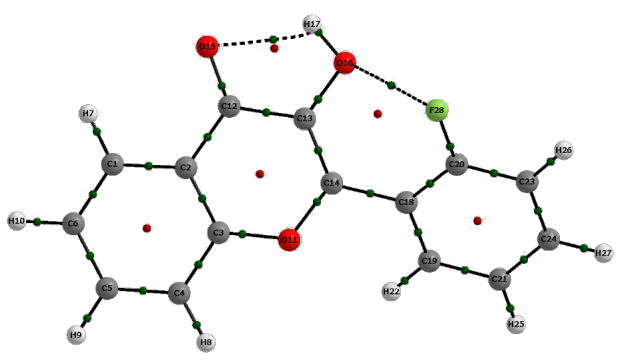

B

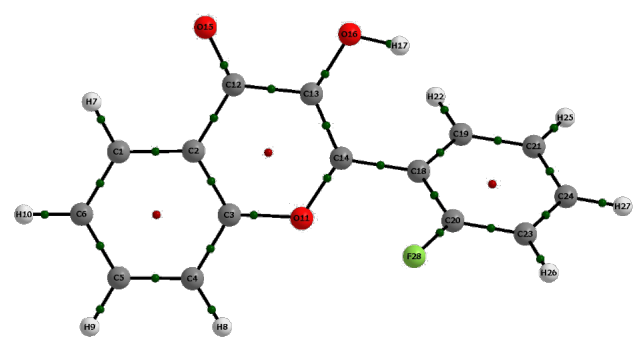

D

Figure 2: Stable conformers of 2'-fluoroflavonol. 
the conformational preferences of the flavonols under study, except for the $\mathrm{C}^{\cdots} \mathrm{H}(\mathrm{O})$ interaction of flavonol B (Table 3). The boldface values in the Table 3 are the reference atoms, i.e., hydrogen atoms that have smaller $q(\mathrm{H}), E(\mathrm{H}), \mathrm{M}_{1}(\mathrm{H})$ and $V(\mathrm{H})$ than the reference establish a stable HB.

Table 3: QTAIM parameters (a.u.) for the hydrogen involved in HB and the halogens involved in electrostatic halogen bonding.

\begin{tabular}{|c|c|c|c|c|}
\hline X (Conformer) & $q(\Omega)$ & $E(\Omega)$ & $\mathrm{M}_{1}(\Omega)$ & $V(\Omega)$ \\
\hline \multicolumn{5}{|l|}{$H(A)$} \\
\hline $\mathrm{H}(\mathrm{O})$ & +0.601 & -0.356 & 0.145 & 17.921 \\
\hline $\mathrm{H}(\mathrm{C})$ & +0.082 & -0.599 & 0.113 & 39.732 \\
\hline \multicolumn{5}{|l|}{$H(B)$} \\
\hline $\mathrm{H}(\mathrm{O})$ & +0.567 & -0.379 & 0.165 & 21.108 \\
\hline $\mathrm{H}(\mathrm{C})$ & +0.045 & -0.606 & 0.134 & 46.738 \\
\hline \multicolumn{5}{|l|}{$F(A)$} \\
\hline $\mathrm{H}(\mathrm{O})$ & +0.620 & -0.331 & 0.151 & 17.809 \\
\hline $\mathrm{H}(\mathrm{C})$ & +0.043 & -0.605 & 0.121 & 44.374 \\
\hline \multicolumn{5}{|l|}{$F(B)$} \\
\hline $\mathrm{H}(\mathrm{O})$ & +0.599 & -0.358 & 0.148 & 18.626 \\
\hline \multicolumn{5}{|l|}{$F(C)$} \\
\hline$H(O)$ & +0.623 & -0.341 & 0.131 & 14.335 \\
\hline \multicolumn{5}{|l|}{$F(D)$} \\
\hline$H(O)$ & +0.567 & -0.379 & 0.165 & 21.744 \\
\hline $\mathrm{H}(\mathrm{C})$ & +0.047 & -0.604 & 0.134 & 47.458 \\
\hline \multicolumn{5}{|l|}{$\mathrm{Cl}(\mathrm{A})$} \\
\hline $\mathrm{H}(\mathrm{O})$ & +0.598 & -0.358 & 0.148 & 18.584 \\
\hline \multicolumn{5}{|l|}{$\mathrm{Cl}(\mathrm{B})$} \\
\hline $\mathrm{H}(\mathrm{O})$ & +0.567 & -0.379 & 0.165 & 22.029 \\
\hline \multicolumn{5}{|l|}{$\mathrm{Br}(\mathrm{A})$} \\
\hline $\mathrm{H}(\mathrm{O})$ & +0.598 & -0.358 & 0.148 & 18.584 \\
\hline \multicolumn{5}{|l|}{$\mathrm{Br}(\mathrm{B})$} \\
\hline $\mathrm{H}(\mathrm{O})$ & +0.567 & -0.379 & 0.165 & 22.029 \\
\hline
\end{tabular}

2'-Fluoroflavonol exhibits four stable conformers, in which those with the hydroxy hydrogen directed toward the carbonyl oxygen (A and B) are significantly more stable than the other two conformers (Table 1); clearly, the intramolecular HB $\mathrm{O}-\mathrm{H} \cdots \mathrm{O}=\mathrm{C}$ plays the determinant role for the conformational isomerism of 2'-fluoroflavonol, as confirmed by NBO $\left(n_{\mathrm{O}(=\mathrm{C})} \rightarrow \sigma^{*} \mathrm{OH} \geq 5 \mathrm{kcal} \mathrm{mol}^{-1}\right)$ and QTAIM calculations (Table 1 and Table 2). The most stable form (A, Figure 2) has the hydroxy oxygen far from the fluorine atom bonded to the adjacent phenyl ring and, according to QTAIM data, it establishes two other stabilizing interactions: Weak HB $\mathrm{H}-\mathrm{O} \cdots \mathrm{H}-\mathrm{C}$ and a nonbonding $\mathrm{F} \cdots \mathrm{O}$ interaction. The formation of the nonbonding $\mathrm{F} \cdots \mathrm{O}$ interaction in conformer $\mathrm{A}$, having fluorine as electron acceptor, is supposed to be due to the partial negative atomic charge on the ether oxygen and a less negative atomic charge on the fluorine atom (the QTAIM atomic charges are -0.619 for $\mathrm{F}$ and -1.075 for $\mathrm{O}$ ). Conformer $\mathrm{B}$, in which fluo- rine is close to the hydroxy oxygen, is calculated to be $0.5 \mathrm{kcal}$ $\mathrm{mol}^{-1}$ less stable than A. According to the classical sense, this energy difference would be attributed to dipolar repulsion between the polar bonds; however, the QTAIM calculations indicate that the interaction between fluorine and oxygen is attractive, suggesting the establishment of a nonbonding $\mathrm{F} \cdots \mathrm{O}$ interaction of similar magnitude to that found in conformer $\mathrm{A}$ (see the electronic density along with BCP and the Laplacian values in Table 2). In this case, the fluorine atom is the electron acceptor (QTAIM atomic charge of -0.620 for F against -1.093 for the hydroxy oxygen), which is not so uncommon, as stated in classical textbooks on aromatic electrophilic substitution, since a resonant structure with a $\mathrm{C}=\mathrm{F}^{+}$contribution can take place [31]; this is shown by NBO calculations, which indicate an interaction responsible for this resonance $\left(n_{\mathrm{F}} \rightarrow \pi^{*}{ }_{\mathrm{C} 1 \mathrm{C} 2}\right)$ of ca. $20 \mathrm{kcal} \mathrm{mol}^{-1}$ (Table 1). Therefore, the difference in stability between $\mathrm{A}$ and $\mathrm{B}$ can be estimated to be due to the weak $\mathrm{HB} \mathrm{H}-\mathrm{O} \cdots \mathrm{H}-\mathrm{C}$ together with the slightly covalent character of $\mathrm{C}=\mathrm{O} \cdots \mathrm{H}-\mathrm{O}$ in $\mathrm{A}$.

Moreover, conformer $\mathrm{C}$ is predicted to be more stable than $\mathrm{D}$ by $0.7 \mathrm{kcal} \mathrm{mol}^{-1}$. Again, the basic difference between them is the orientation of the fluorine atom, in which $\mathrm{C}$ experiences intramolecular $\mathrm{HB} \mathrm{O}-\mathrm{H} \cdots \mathrm{F}-\mathrm{C}$ according to the electron delocalizations obtained by NBO (sum of $n_{\mathrm{F}} \rightarrow \sigma^{*} \mathrm{OH}=8.2 \mathrm{kcal}$ $\mathrm{mol}^{-1}$ ), as well as by QTAIM results (Table 1 and Table 2). There is not an attractive interaction observed for $\mathrm{D}$ by means of QTAIM calculations; therefore, the energy difference between $\mathrm{C}$ and $\mathrm{D}$ is expected to be due to the intramolecular $\mathrm{HB}$ $\mathrm{O}-\mathrm{H} \cdots \mathrm{F}-\mathrm{C}$. Furthermore, the longer $\mathrm{C}-\mathrm{X}$ distance and weaker $n_{\mathrm{F}} \rightarrow \pi^{*} \mathrm{CC}$ electron delocalization in $\mathrm{C}$ than in the remaining conformers (Table 1) provide evidence that fluorine lone pairs in $\mathrm{C}$ are involved in intramolecular $\mathrm{HB} \mathrm{O}-\mathrm{H} \cdots \mathrm{F}-\mathrm{C}$ instead of contributing to the resonant structure with $\mathrm{C}=\mathrm{F}^{+}$. $\mathrm{HB}$ involving fluorine as a proton acceptor when bonded to carbon is unusual [4], but it has been shown to be of secondary, not negligible, importance for the conformational isomerism of 2'-fluoroflavonol in this work.

The conformational behaviours of chlorine and bromine derivatives are quite similar to each other, given the energy difference between the two stable conformers and their geometrical parameters (Table 1 and Supporting Information File 1). According to QTAIM calculations, conformer A of both 2'-haloflavonols experiences intramolecular $\mathrm{HB} \mathrm{C}=\mathrm{O} \cdots \mathrm{H}-\mathrm{O}$ and, to a lesser extent, a nonbonding $\mathrm{C}-\mathrm{X} \cdots \mathrm{O}-\mathrm{C}$ interaction, while conformer $\mathrm{D}$, in which the halogen is far from the hydroxy group and the hydroxy hydrogen is not directed toward the carbonyl oxygen, does not exhibit any attractive interaction like these ones. Again, the conformational isomerism of 2'-chloro and 2 '-bromoflavonol is governed by the intramolecular HB 
$\mathrm{C}=\mathrm{O} \cdots \mathrm{H}-\mathrm{O}$ (see $\mathrm{NBO} n_{\mathrm{O}(=\mathrm{C})} / \sigma^{*} \mathrm{OH}$ electron delocalizations and QTAIM $\mathrm{C}=\mathrm{O} / \mathrm{HO}$ electron densities and Laplacian in Table 1 and Table 2), but a nonbonding $\mathrm{C}-\mathrm{X} \cdots \mathrm{O}-\mathrm{C}$ interaction also operates in $\mathrm{A}$. The nonbonding $\mathrm{C}-\mathrm{X} \cdots \mathrm{O}-\mathrm{C}$ interaction in chlorine and bromine derivatives is expected to be inferior to that in 2 -fluoroflavonol, given the lower $n_{\mathrm{X}} / \pi^{*} \mathrm{CC}$ delocalization energies, making the contribution of $\mathrm{C} \mathrm{Cl}^{+}$and $\mathrm{C}=\mathrm{Br}^{+}$less significant for the resonance structure; also, both intramolecular $\mathrm{HB}$ and nonbonding $\mathrm{C}-\mathrm{X} \cdots \mathrm{O}-\mathrm{C}$ interactions with $\mathrm{OH}$ are impossible for the chlorine and bromine derivatives, since the halogen in the optimized conformers $\mathrm{A}$ and $\mathrm{D}$ are not directed toward $\mathrm{OH}$.

\section{Conclusion}

Overall, the intramolecular $\mathrm{HB} \mathrm{C}=\mathrm{O} \cdots \mathrm{H}-\mathrm{O}$ is the dictating force of the conformational equilibrium of 2'-haloflavonols, but a nonbonding $\mathrm{C}-\mathrm{X} \cdots \mathrm{O}-\mathrm{C}$ interaction is also operating. Other intramolecular HBs are experienced by 2 '-fluoroflavonol, including in particular an unusual $\mathrm{C}-\mathrm{F} \cdots \mathrm{H}-\mathrm{O}$ interaction. In fact, the strong resonant structure due to the $\mathrm{C}-\mathrm{X} \cdots \mathrm{O}-\mathrm{C}$ interaction in ortho position to a benzene ring conjugated with an $\alpha, \beta$-unsaturated ketone is supposed to favour the $\mathrm{C}=\mathrm{X}^{+}$contribution and, therefore, to establish nonbonding $\mathrm{C}-\mathrm{X} \cdots \mathrm{O}-\mathrm{C}$ interactions, in addition to intramolecular $\mathrm{HB}$, especially for the fluorine derivative. Thus, our findings suggest that nonbonding $\mathrm{C}-\mathrm{X} \cdots \mathrm{O}-\mathrm{C}$ interactions may be a driving force toward the bioactive conformation of molecules.

\section{Supporting Information}

\section{Supporting Information File 1}

Optimized structures for all minima of 2'-haloflavonols and the corresponding Cartesian coordinates.

[http://www.beilstein-journals.org/bjoc/content/ supplementary/1860-5397-8-12-S1.pdf]

\section{Acknowledgements}

The authors thank FAPEMIG and FAPESP for the financial support of this research, as well as to CNPq and FAPESP for fellowships and a studentship.

\section{References}

1. Beijer, F. H.; Kooijman, H.; Spek, A. L.; Sijbesma, R. P.; Meijer, E. W. Angew. Chem., Int. Ed. 1998, 37, 75-78.

doi:10.1002/(SICI)1521-3773(19980202)37:1/2<75::AID-ANIE75>3.0.C O;2-R

2. Pinheiro, J. R.; Bitencourt, M.; da Cunha, E. F. F.; Ramalho, T. C.; Freitas, M. P. Bioorg. Med. Chem. 2008, 16, 1683-1690. doi:10.1016/j.bmc.2007.11.020

3. Duarte, C. J.; Freitas, M. P. J. Mol. Struct. 2009, 930, 135-139. doi:10.1016/j.molstruc.2009.05.004
4. Dunitz, J. D.; Taylor, R. Chem.-Eur. J. 1997, 3, 89-98. doi:10.1002/chem.19970030115

5. Mallory, F. B.; Mallory, C. W.; Baker, M. B. J. Am. Chem. Soc. 1990, 112, 2577-2581. doi:10.1021/ja00163a015

6. Matta, C. F.; Castillo, N.; Boyd, R. J. J. Phys. Chem. A 2005, 109, 3669-3681. doi:10.1021/jp045044z

7. Palusiak, M.; Grabowski, S. J. Struct. Chem. 2008, 19, 5-11. doi:10.1007/s11224-007-9244-0

8. Grabowski, S. J.; Małecka, M. J. Phys. Chem. A 2006, 110, 11847-11854. doi:10.1021/jp064997p

9. Alkorta, I.; Elguero, J. Struct. Chem. 2004, 15, 117-120. doi:10.1023/B:STUC.0000011246.24486.63

10. Zordan, F.; Brammer, L.; Sherwood, P. J. Am. Chem. Soc. 2005, 127, 5979-5989. doi:10.1021/ja0435182

11. Metrangolo, P.; Resnati, G. Science 2008, 321, 918-919. doi:10.1126/science.1162215

12. Verbeek, R.; Plomp, A. C.; van Tol, E. A. F.; van Noort, J. M. Biochem. Pharmacol. 2004, 68, 621-629. doi:10.1016/j.bcp.2004.05.012

13. Bader, R. F. W. Atoms in Molecules: A Quantum Theory; Oxford University Press: Oxford, 1990.

14. Bader, R. F. W. Chem. Rev. 1991, 91, 893-928. doi:10.1021/cr00005a013

15. Bader, R. F. W. J. Phys. Chem. A 1998, 102, 7314-7323. doi:10.1021/jp981794v

16. Grabowski, S. J. Chem. Rev. 2011, 111, 2597-2625. doi:10.1021/cr800346f

17. Koch, U.; Popelier, P. L. A. J. Phys. Chem. 1995, 99, 9747-9754. doi:10.1021/j100024a016

18. Glendening, E. D.; Reed, A. E.; Carpenter, J. E.; Weinhold, F. NBO, Version 5.0, included in the Gaussian09 package of programs, Gaussian Inc., Wallingford, CT, 2009.

19. Wallet, J. C.; Gaydou, E. M.; Molins, E.; Miravitlles, C. Z. Kristallogr. 1994, 209, 746-748. doi:10.1524/zkri.1994.209.9.746

20. Lu, H.; Chang, D. J.; Baratte, B.; Meijer, L.; Schulze-Gahmen, U. J. Med. Chem. 2005, 48, 737-743. doi:10.1021/jm049353p

21. Wiseman, R. L.; Zhang, Y.; Lee, K. P. K.; Harding, H. P.; Haynes, C. M.; Price, J.; Sicheri, F.; Ron, D. Mol. Cell 2010, 38, 291-304. doi:10.1016/j.molcel.2010.04.001

22. Cioslowski, J.; Mixon, S. T. J. Am. Chem. Soc. 1992, 114, 4382-4387. doi:10.1021/ja00037a053

23. Bickelhaupt, F. M.; Baerends, E. J. Angew. Chem. 2003, 115, 4315-4320. doi:10.1002/ange.200350947

24. Bader, R. F. W. Chem.-Eur. J. 2006, 12, 2896-2901. doi:10.1002/chem.200501589

25. Bader, R. F. W. J. Phys. Chem. A 2009, 113, 10391-10396. doi:10.1021/jp906341r

26. Bader, R. F. W. J. Phys. Chem. A 2010, 114, 7431-7444. doi:10.1021/jp102748b

27. Rozas, I.; Alkorta, I.; Elguero, J. J. Am. Chem. Soc. 2000, 122, 11154-11161. doi:10.1021/ja0017864

28. Espinosa, E.; Alkorta, I.; Elguero, J.; Molins, E. J. Chem. Phys. 2002, 117, 5529-5542. doi:10.1063/1.1501133

29. Bondi, A. J. Phys. Chem. 1964, 68, 441-451. doi:10.1021/j100785a001

30. Gilli, G.; Gilli, P. The Nature of the Hydrogen Bond: Outline of a Comprehensive Hydrogen Bond Theory; Oxford University Press: Oxford, 2009.

31. Rosenthal, J.; Schuster, D. I. J. Chem. Educ. 2003, 80, 679-690. doi:10.1021/ed080p679 


\section{License and Terms}

This is an Open Access article under the terms of the Creative Commons Attribution License

(http://creativecommons.org/licenses/by/2.0), which permits unrestricted use, distribution, and reproduction in any medium, provided the original work is properly cited.

The license is subject to the Beilstein Journal of Organic Chemistry terms and conditions:

(http://www.beilstein-journals.org/bjoc)

The definitive version of this article is the electronic one which can be found at:

doi:10.3762/bjoc.8.12 